\title{
INOCULATION OF BALB/C MICE WITH Lacazia Ioboi
}

\begin{abstract}
SUMMARY
In a previous study, the authors inoculated Swiss mice with Lacazia loboi (L. loboi) and succeeded in maintaining a granulomatous infiltrate and viable fungal cells up to one year and six months after inoculation. Considering the experimental work on paracoccidioidomycosis, $0.03 \mathrm{ml}$ of a fungal suspension obtained from a biopsy of a Jorge Lobo's Disease patient were inoculated into both hind foot pads of 32 six week-old BALB/c mice of both sexes. The animals were sacrificed 1, 4, 7 and 10 months post inoculation. The suspension contained $1.3 \times 10^{6}$ fungi/ml and presented $38 \%$ viability. Seven months after inoculation, most of the animals presented profuse infiltrates consisting of isolated histiocytes, foreign body and Langhans' giant cells and a large number of fungi, most of them viable. Emergence of macroscopic lesions was observed during the $8^{\text {th }}$ month. Based on fungal count, viability index before and after inoculation, presence of macroscopic lesions and histopathological findings similar to the findings in humans, the authors believe that BALB/c mice may be a good experimental model to study Jorge Lobo's Disease, mainly regarding therapeutic evaluation.
\end{abstract}

KEYWORDS: Jorge Lobo's Disease; Lacazia loboi; Paracoccidioides; BALB/c mice.

\section{INTRODUCTION}

The etiological agent of Jorge Lobo's Disease, Lacazia loboi ( $L$. loboi), has not yet been cultivated in the laboratory ${ }^{6}$. An experimental model to study the pathogenesis of this disease and to be used as an additional tool in therapeutic investigations is highly desirable.

The mouse is the species most frequently used in experimental studies on paracoccidioidomycosis. BALB/c, B10.A, C57/B1/10 and CBA are the mouse strains most commonly used. The route of inoculation and the strains are key factors for the development of infection. BALB/c mice are susceptible to Paracoccidioides brasiliensis (P. brasiliensis) when inoculated by the intranasal route, but only show intermediate susceptibility when inoculated intraperitoneally ${ }^{5}$.

Several attempts have been carried out to inoculate L. loboi in different animals such as monkeys, guinea-pigs, rats, mice, hamsters, tortoises, armadillos, and others, using different routes ${ }^{1,2,4,7,8,9,10,12,14}$, with a small number of positive but inconsistent results.

In a previous study we inoculated Swiss mice with material from biopsies of 9 patients with this mycosis, using a fungal concentration whose number and viability index were known. One year and six months after inoculation the results showed an increase in the infiltrates, consisting of macrophages with a large number of fungi, although most of them were unviable. Nevertheless, a small number of parasitic cells was still alive as evidenced by the fluorescein diacetate-ethidium bromide (FD-EB) staining technique ${ }^{13}$

Even though the process was active after such a long period, the small number of still viable fungi did not allow the use of these mice as an experimental model for the study of Jorge Lobo's Disease.

At that time, we mentioned that there could be other strains of mice more susceptible to L. loboi just as is the case with P. brasiliensis and that, depending on the inoculation route, different strains may show differences in susceptibility 5 .

Therefore, having studied BALB/c mice inoculated with a known quantity of fungi with a known viability index, the results obtained suggested that this strain is susceptible to L. loboi.

\section{MATERIAL AND METHODS}

1. Biopsy: a single keloid lesion fragment was collected from a Jorge Lobo's Disease patient with disseminated lesions, from the State of Acre. The fragment was immediately macerated in $0.85 \%$ saline solution

2. Fungal viability: fungal viability was determined by vital staining with FD-EB ${ }^{3}$, standardized for $L$. loboi by VILANI-MORENO \& OPROMOLLA ${ }^{13}$. 
3. Fungal concentration in the suspension: fungal concentration was estimated using a Neubauer chamber and the results were expressed as absolute numbers. The suspension contained $1.3 \times 10^{6}$ fungi/ml with a $38 \%$ viability index.

4. Inoculation: both hind foot pads of 32 six week-old BALB/c mice of both sexes, from the "Instituto Lauro de Souza Lima" animal facilities, were intradermally inoculated with $0.03 \mathrm{ml}$ fungal suspension/ foot. The animals were maintained at a temperature ranging from 22 to $25^{\circ} \mathrm{C}$, with free access to commercial pelleted food and filtered water.

5. Sacrifice schedule: the animals were randomly allocated to 4 groups and respectively sacrificed after 1 month (group I) and after 4 (group II) , 7 (group III) and 10 (group IV) months.

6. Foot pad exeresis: both foot pads were excised, the right foot pads were submitted to histopathological examination and the left were macerated in $1 \mathrm{ml} 0.85 \%$ saline solution to count the fungi and to determine their viability. The histological sections were stained with hematoxylin-eosin (HE) and methenamine-silver (MS).

\section{RESULTS}

The histopathological study showed that at one month after inoculation there was a small infiltrate made up of macrophages, cells with clear cytoplasm, scarce lymphocytes and some fibroblasts. The fungi were located intracellularly, were rare, and usually present as empty capsules devoid of protoplasm.

After four months, the granuloma was larger, sometimes nodular, and made up of the same kind of cells. In some areas the macrophages presented a syncytial aspect. A large number of fungi was observed, many of them with preserved morphology. MS staining demonstrated fungi with isolated forms, single and multiple budding, and some catenulated forms.

After 7 and 10 months, granulomas were extensive, nodular, divided into blocks by fibrous septa, made up of modified macrophages and numerous giant cells (foreign body and Langhans), containing a large number of fungi. In a few areas the infiltrate showed a syncytial aspect lacking macrophage individualization (Fig. 1 and 2). In addition, there were groups of giant cells and fragmented neutrophils. MS staining demonstrated catenulated forms of several sizes (Fig. 3).

Some mice started to show macroscopic lesions in the foot pads 7 months after inoculation. The volume of the foot pads was enlarged due to the appearance of nodules of hard consistency and with a smooth surface, and a few dilated and sinuous vessels were present on the dorsal and plantar surface. Two animals presenting such lesions and allocated to group IV were sacrificed in the $9^{\text {th }}$ month. Among the 8 mice sacrificed after 9 months, 6 presented macroscopic lesions (Fig. 4).

Viability and number of fungi recovered after sacrifice at different time intervals are described in Table 1.

\section{DISCUSSION}

The data in Table 1 show an increased number of fungi during the experimental period. This was associated with the increased size of the granulomas, and consequently, with enlargement of the inoculated foot pad. By the end of the investigation, the amount of fungi obtained from seven animals was higher than the inoculated number, suggesting multiplication of the parasites. Table 1 also shows that the highest number of viable fungi was found in group IV, but none of the groups showed viability superior to that observed in the inoculum.

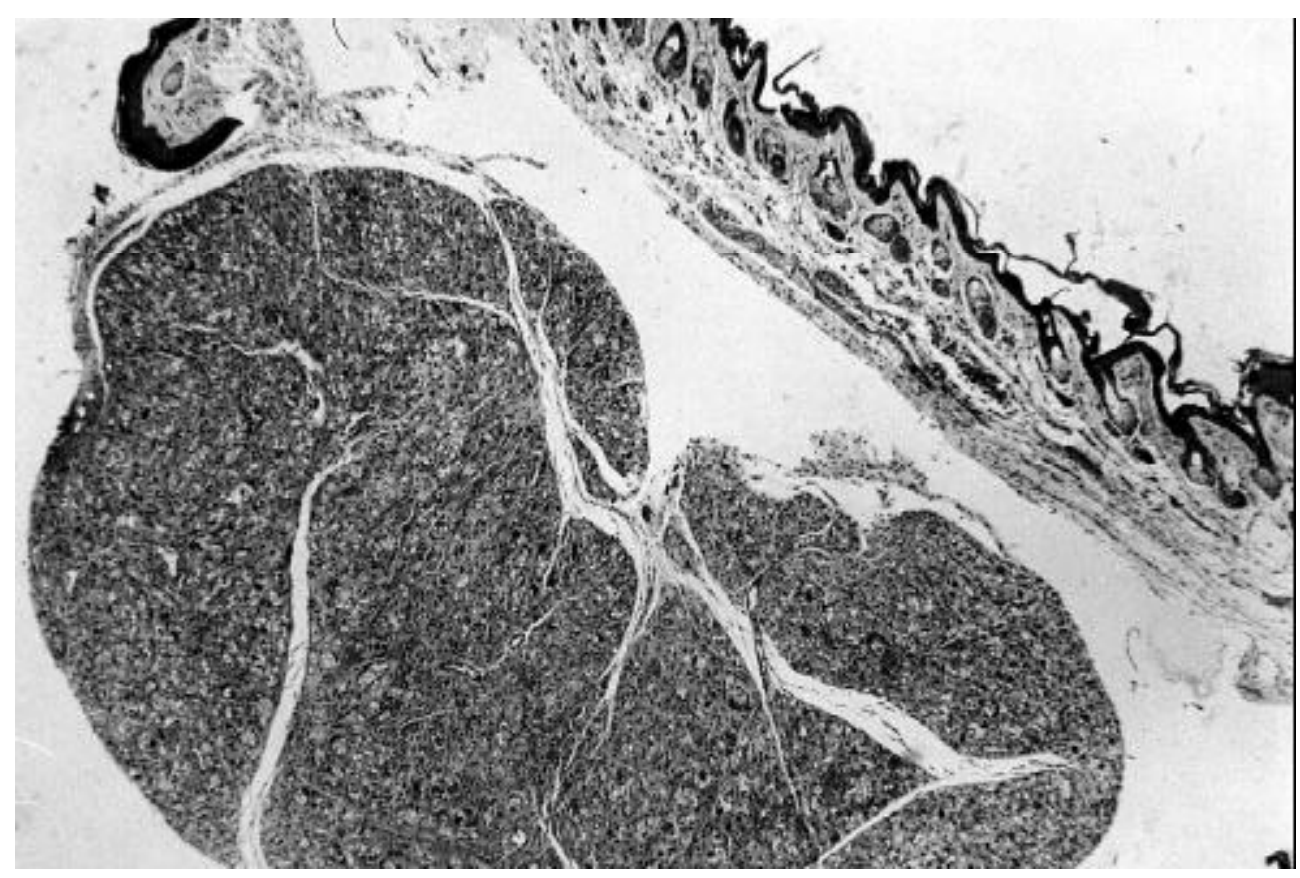

Fig. 1 - General view of the skin granuloma. Large nodule localized in the middle dermis (HE; 50X). 


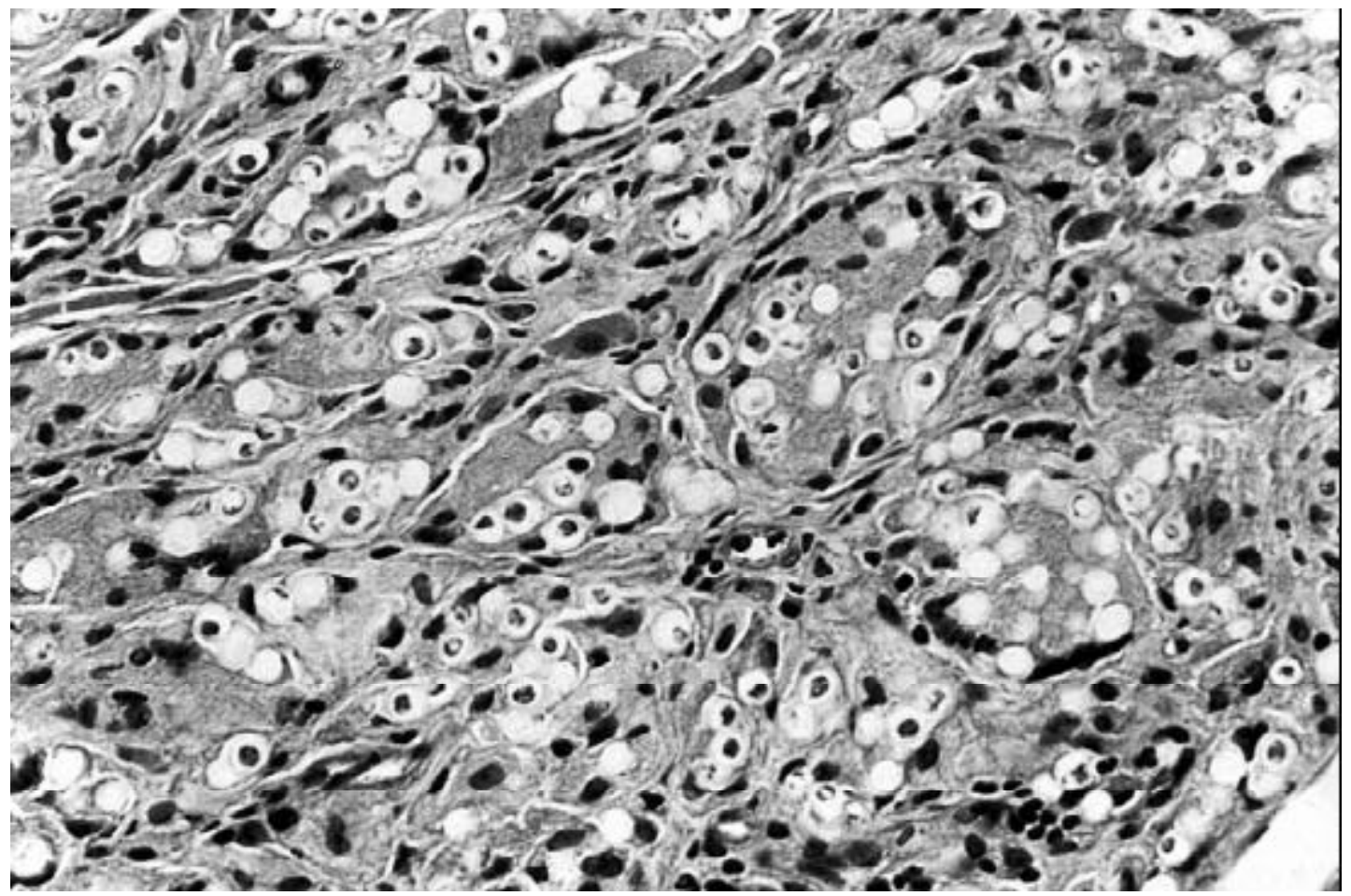

Fig. 2 - A closer view of the granulomatous infiltrate with a large number of macrophages and fungal cells (HE; 400X).

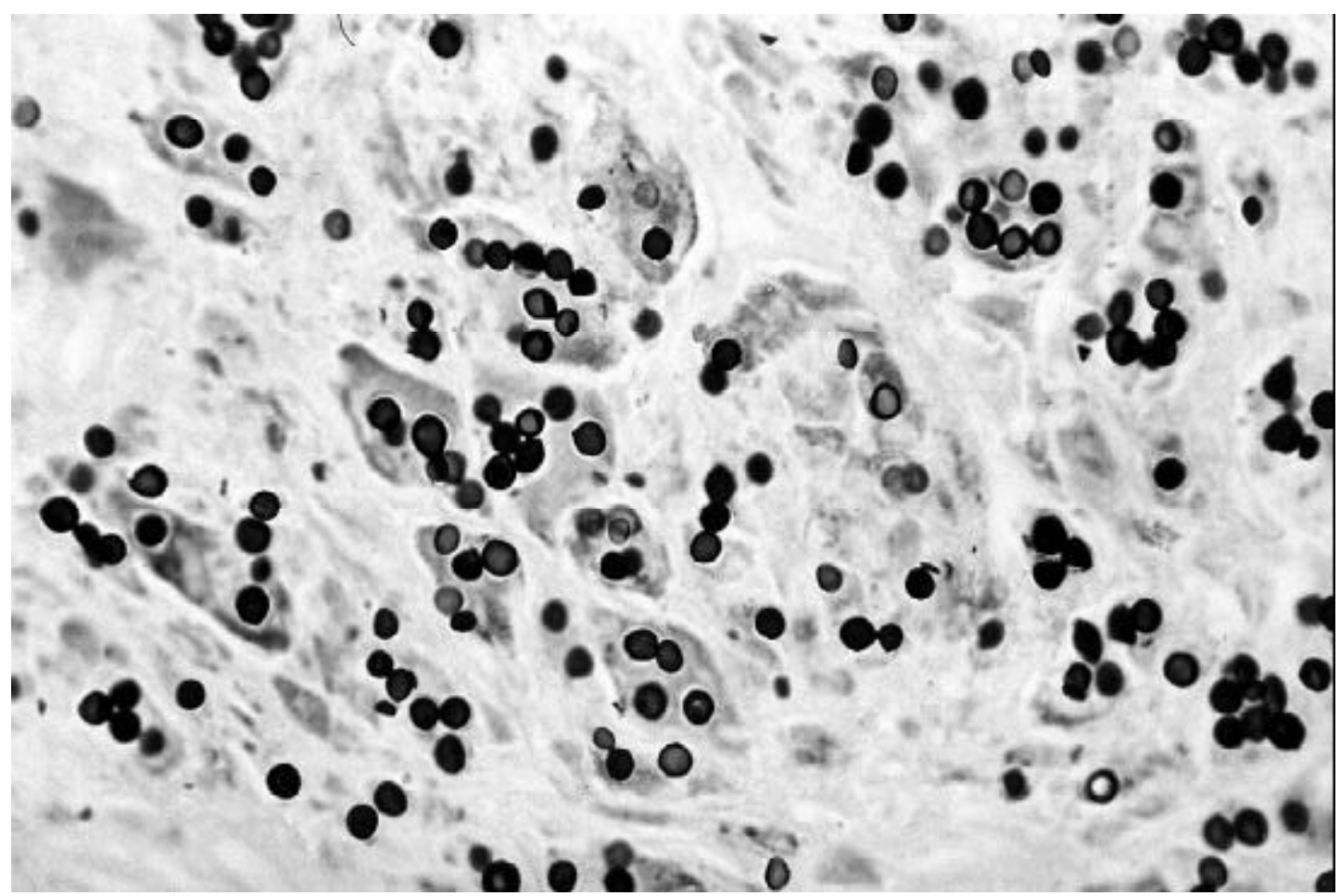

Fig. 3 - Large number of fungi visualized by methenamine-silver staining (400X) 


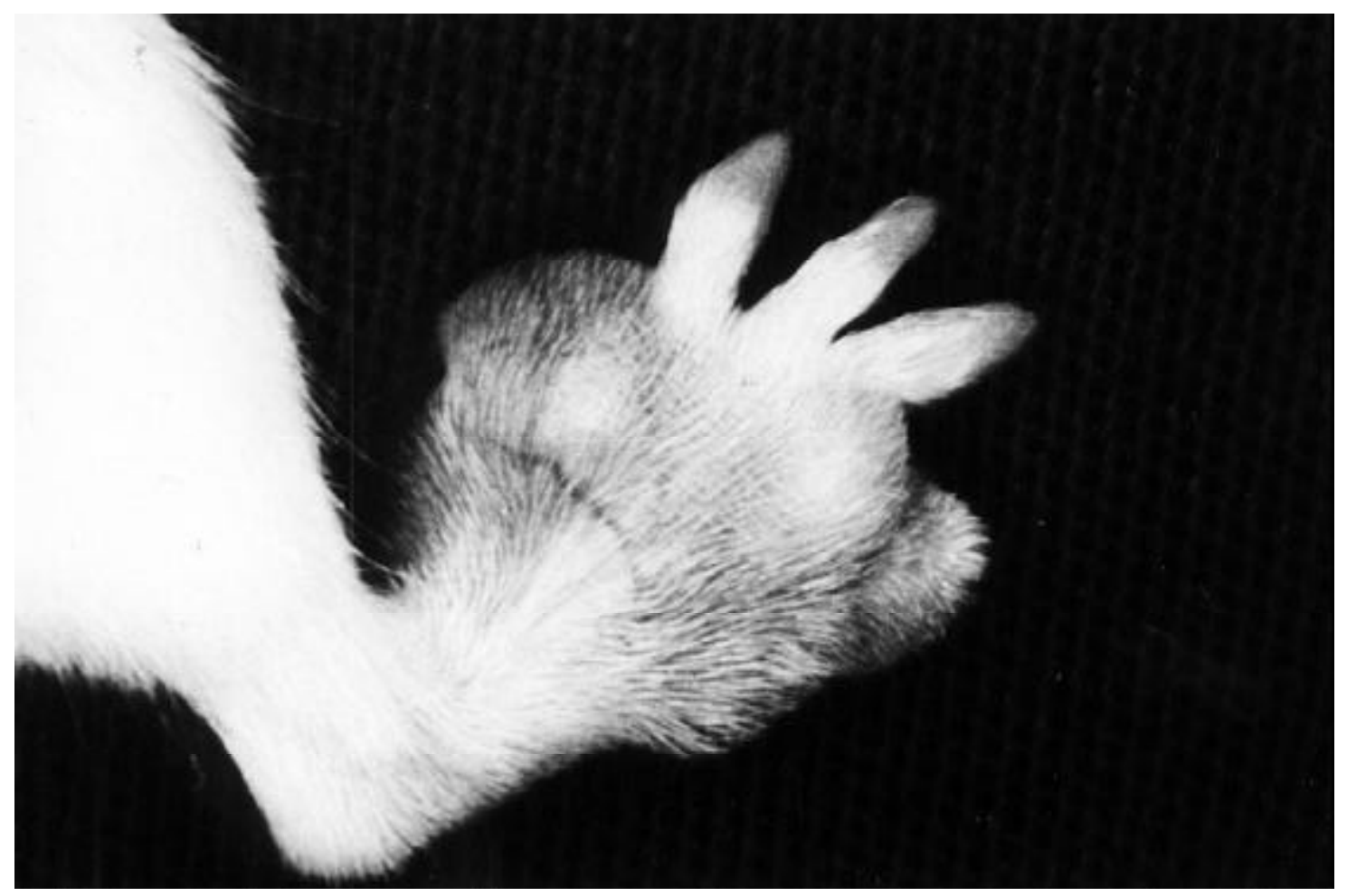

Fig. 4 - Macroscopic aspect of the foot of a mouse nine months after inoculation with L. loboi.

Table 1

Number and viability of fungi recovered after sacrifice at different time intervals

\begin{tabular}{ccc}
\hline Group & $\begin{array}{c}\text { Number of fungi } \\
\text { (lowest and highest values) }\end{array}$ & Viability \\
\hline I & $2.5 \times 10^{3}$ to $3.2 \times 10^{4}$ & $\begin{array}{c}\text { Negative in } 6 \text { animals; } \\
\text { positive in } 2\end{array}$ \\
II & $2.0 \times 10^{4}$ to $3.9 \times 10^{5}$ & $\begin{array}{c}\text { Negative in } 4 \text { animals; } \\
\text { positive in } 4 \\
\text { III }\end{array}$ \\
IV & $1.7 \times 10^{4}$ to $2.2 \times 10^{6}$ & $\begin{array}{c}\text { Negative in } 5 \text { animals; } \\
\text { positive in } 3 \\
\text { Negative in } 1 \text { animal; } \\
\text { positive in } 7\end{array}$ \\
\hline
\end{tabular}

The histopathological data obtained after different time intervals showed the presence of macrophages and giant cells after 4 months. There was also a reduction of cells with clear cytoplasm after 7 and 10 months. The histological picture of this mouse strain was very similar to that observed in lesions from Jorge Lobo's Disease patients. Granulomas presented the same type of cells, lymphocytes were rare, but considerable quantities of neutrophils and plasma cells scattered or forming small groups in the inflammatory infiltrate were observed. It is possible that these neutrophils were related to small foci of necrosis, though no evidence was obtained in this respect, and the presence of plasma cells was related to antibody production. Similarly to other types of chronic inflammation, there was also a considerable increase of collagen fibers and fibroblasts in the lesions of animals sacrificed 10 months after inoculation. The fibrous septa intersecting the granulomatous infiltrate seemed to be trying to contain the advancement of the process and their proliferation may have contributed to the enlargement of the foot.

Since $100 \%$ of the animals showed signs of infection, their granulomatous infiltrates were almost identical to those observed in human disease and macroscopic lesions were present, BALB/c mice represent a good experimental model to study this mycosis. In addition, the number of fungi in these lesions was also very large with a high viability index, to the extent that at 10 months after inoculation, viability was approximately $20 \%$, reaching $31 \%$ in one animal.

SHEPARD in $1960^{11 .}$ showed the limited but rather constant multiplication of Mycobacterium leprae in the foot pad of BALB/c mice during periods of 6 to 7 months. This model made it possible to determine the multiplication rate of these mycobacteria not yet cultivable in vitro and the period of their viability outside the human body. Besides the use of drugs which limit their growth, the mode of action of these drugs (bactericidal or bacteriostatic), and whether strains of bacteria isolated from patients are resistant to the drugs used in their treatment, could also be studied.

Therefore, it seems possible that studies related to L. loboi could be of the same type as those used for the experimental investigation of leprosy. Priority, of course, will be given to therapeutical investigations in order to find a drug or group of drugs to eliminate this disease that, although affecting only a small proportion of the population in the 
Amazon region, afflicts a large number of people imposing limitations on their normal activities.

\section{RESUMO}

\section{Inoculação de Lacazia loboi em camundongos BALB/c}

Em trabalho anterior, os autores inocularam camundongos Suíços com o Lacazia loboi (L. loboi) conseguindo a manutenção de um infiltrado granulomatoso e células fúngicas viáveis por até um ano e 6 meses após a inoculação. Considerando-se trabalhos experimentais realizados na paracoccidioidomicose, eles inocularam $0,03 \mathrm{ml} d e$ suspensão fúngica, obtida de biópsia de lesão de um paciente portador da doença de Jorge Lobo, em ambos coxins plantares traseiros de 32 camundongos BALB/c, de ambos os sexos e com 6 semanas de idade. Os animais foram sacrificados com 1, 4, 7 e 10 meses pós-inoculação. A suspensão possuía $1.3 \times 10^{6}$ de fungos $/ \mathrm{ml}$ e $38 \%$ de índice de viabilidade. Após 7 meses de inoculação a maioria dos animais já apresentava um infiltrado exuberante constituído por histiócitos isolados, células gigantes tipo corpo estranho e tipo Langhans, grande quantidade de fungos, na sua maior parte viáveis; no $8^{\circ}$ mês observou-se o aparecimento de lesões macroscópicas. Tendo como base a contagem do número de fungos, índice de viabilidade antes e após inoculação, presença de lesões macroscópicas e achados histopatológicos semelhantes ao humano, os autores acreditam que os camundongos BALB/c possam se constituir em um bom modelo experimental para o estudo da doença de Jorge Lobo, principalmente com relação às pesquisas terapêuticas.

\section{REFERENCES}

1. AZULAY, R.D. \& MIRANDA, J. - Doença de Jorge Lôbo ( $15^{\circ}$ caso da literatura). Hospital (Rio de J.), 51: 685-691, 1957.

2. AZULAY, R.D.; ANDRADE, L.C.; SILVA, D. \& CARNEIRO, J. - Reprodução experimental da blastomicose de Jorge Lôbo. An. bras. Derm., 43: 261-266, 1968.

3. CALICH, V.L.G.; PURCHIO, A. \& PAULA, C.R. - A new fluorescent viability test for fungi cells. Mycopathologia (Den Haag), 66: 175-177, 1979
4. CERRUTI, H. \& ZAMITH, V.A. - Doença de Jorge Lôbo. (Comunicação à Sociedade Paulista de Medicina em 1948)

5. COELHO, K.I.R.; DEFAVERI, J.; REZKALLAH-IWASSO, M.T. \& PERAÇOLI, M.T.S - Experimental paracoccidioidomycosis. In: FRANCO, M.; LACAZ, C.S.; RESTREPO-MORENO, A. \& DEL NEGRO, G., ed. Paracoccidioidomycosis. Boca Raton, CRC Press, 1994. p. 87-102.

6. LACAZ, C.S.; PORTO, E. \& MARTINS, J.E.C. - Micologia médica: fungos, actinomicetos e algas de interesse médico. 8. ed. São Paulo, Sarvier, 1991

7. LOBO, J. - Contribuição ao estudo das blastomicoses. An. Fac. Med. Recife, 39: 4-5, 1938

8. SAMPAIO, M.M. \& DIAS, L.B. - Experimental infection of Jorge Lôbo's disease in the cheek-pouch of the golden hamster (Mesocricetus auratus). Rev. Inst. Med. trop. S. Paulo, 12: 115-120, 1970 .

9. SAMPAIO, M.M.; DIAS, L.B. \& SCAFF, L. - Bizarre forms of the aetiologic agent in experimental Jorge Lôbo's disease in tortoises. Rev. Inst. Med. trop. S. Paulo, 13 $191-193,1971$.

10. SAMPAIO, M.M. \& DIAS, L.B. - The armadillo Euphractus sexcinctus as a suitable animal for experimental studies of Jorge Lôbo's disease. Rev. Inst. Med. trop. S Paulo, 19: 215-220, 1977.

11. SHEPARD, C.C. - The experimental disease that follows the injection of human leprosy bacilli into foot-pads of mice. J. exp. Med., 112: 445-454, 1960.

12. TREJOS, A. \& ROMERO, A. - Contribuição ao estudo das blastomicoses na Costa Rica In: CONGRESSO INTERNACIONAL DE MICROBIOLOGIA, 5., Rio de Janeiro, 1950. Resumos. p. 127.

13. VILANI-MORENO, F.R. \& OPROMOLLA, D.V.A. - Determinação da viabilidade do Paracoccidioides loboi em biópsias de pacientes portadores de doença de Jorge Lôbo. An. bras. Derm., 72: 433-437, 1997.

14. WIERSEMA, J.P. \& NIEMEL, P.L. - Lobo's disease in Surinam patients. Trop. geogr Med., 17: 89-111, 1965

Received: 17 September 1999

Accepted: 11 April 2000 